\title{
Circular Economy and Stakeholder Engagement Strategy*
}

\author{
Daniela M. Salvioni ${ }^{* *}$ Alex Almici ${ }^{* * *}$
}

\begin{abstract}
The transition from the linear economy to the circular one is an epochal challenge for firms. It requires rethinking of the ways to create value according to circular business models. In this context, adoption of a stakeholder engagement strategy based on principles such as involvement, dialogue, and effective fulfillment of stakeholders' expectations is becoming increasingly relevant. This study analyzes the role of stakeholder engagement with respect to the success of circular business models by identifying the main factors that deserve attention in order to ensure an effective shift toward the circular economy.
\end{abstract}

Keywords: Corporate Governance; Circular Economy; Business Models; Stakeholder Engagement; Sustainability

\section{1. "Circular Business Models" and Strategic Implications}

The need to reduce the environmental impact of companies' activities and the increasing attention being paid to sustainability issues underscores the importance of the circular economy as well as a general rethinking of traditional linear economybased business models (Teece, 2010; Ma et al., 2014; Gregson et al., 2015; Haas et al., 2015; Ghisellini et al., 2016; Stahel, 2016; Geissdoerfer et al., 2017; Kirchherr et al., 2017).

The establishment of a competitive advantage has been increasingly linked to the shift from behaviors based on the "take and discard" logic (Hopkinson et al., 2018), typical in a linear economy, toward best practices characterized by the reuse of limited resources according to principles such as efficiency, global responsibility (Salvioni, 2013), sustainability, and ecosystem and health protection (Jackson, 2009; Wells, 2013; Bocken et al., 2014; Kolk, 2016).

The circular economy has been promoted and regulated by international bodies, in particular the European Commission (2012, 2014, 2015, 2020) and the Ellen MacArthur Foundation (2013, 2014, 2015). These bodies identify the circular economy as a virtuous model that complies with a set of key principles, including the following: (a) reuse of resources according to a continuous

\footnotetext{
* The Authors: Salvioni, D. M. §§ 1, 5, Almici, A. §§ 2, 3, 4.

** Full Professor of Business Administration, University of Brescia (daniela.salvioni@unibs.it)

**** Professor of Business Administration, University of Brescia (alex.almici@unibs.it)
}

Salvioni, D. M., \& Almici, A. (2020). Circular Economy and Stakeholder Engagement Strategy. Symphonya. Emerging Issues in Management (symphonya.unicusano.it), (1), 26-44. 
circular process (involving design, production/remanufacturing, distribution, use, reuse, repair, collection, and recycling) (Bonciu, 2014), (b) preservation of the value of products and the materials they are made of, either by lengthening their life or by changing the belief that obsolescence (in functional, economic, regulatory, technological, and aesthetic terms) implies discarding the product (Hollander et al., 2017), (c) elimination of waste by closing the economic and ecological loops of resource flows, $(d)$ promotion of "low impact" growth to reduce greenhouse gas emissions, and (e) uptake of sustainable and non-toxic materials.

Within the field of circular economy, it has been introduced the concept of circular business model which involves creating value via efficient reuse and ecosystem protection (Beattie et al., 2013; Linder et al., 2015). Adherence to the principles of the circular economy involves reorganizing traditional business models, whose main components consist of value proposition, creation, delivery, and capturing (Chesbrough, 2010; Osterwalder et al., 2010; Akanbi et al., 2019). Herein, a new perspective should be followed, which involves (a) promoting the use of renewable energy sources and bio-based fuels (Geisendorf et al., 2017), (b) treating waste as a relevant source of new resources that can be used profitably, rather than as material to be discarded and implying additional costs for the company, (c) reducing downtime by rearranging production processes and promoting the sharing of materials among firms to reduce waste (i.e., industrial symbiosis) (Dentchev et al., 2018), (d) lengthening the life cycles of products/services by strengthening their maintenance, refurbishment, reuse, remanufacturing, and remarketing (Aboulamer, 2017; Geissdoerfer et al., 2017), and (e) ensuring the development of economic processes based on the circular "cradle-to-cradle" logic rather than the traditional "cradle-to-grave" approach (McDonough et al., 2002; Lambin, 2009, 2014).

With reference to the above-mentioned characteristics, scholars have identified different circular business models; however, all of them consider the careful use of resources and related waste reduction as important strategic conditions for firms to gain a competitive advantage (Ranta, 2018). Thus, the circular economy leads companies to rearrange their business models, while focusing on the environment and community by ensuring the engagement of the most relevant stakeholders (OECD, 2019). In this context, value creation requires going beyond the traditional perspective of the "end consumer", which is closely related to a "single stakeholder" view, toward a wider approach including all relevant stakeholders (Tolkamp et al., 2018). Indeed, the circular economy's perspective promotes the evolution of business models that are traditionally customer-centered toward systems that comprehensively engage all stakeholders, such as employees, suppliers, citizens, and the Government (Donaldson et al., 1995).

In fact, the establishment of long-term stakeholder relationships has become increasingly important due to the circular economy, and thus, it is a necessary condition for the effective formulation of a firm's strategy. The implementation of successful business models that can create value in the long term requires that firms pay more attention to all of their stakeholders by ensuring their involvement, maintaining a dialogue with them, and fulfilling their expectations. 
For a firm, the best strategy formulation increasingly depends on the ability of governance bodies to translate stakeholders' expectations into long-term objectives (Almici, 2012). These goals must be achieved by implementing specific economic activities, including the reduction of waste and pollution, recycling of materials, and promotion of responsible consumption. The circular economy requires a general rethinking of the strategic analysis perspective and related business models, implying first and foremost the increased attention to be paid to relevant stakeholders, as well as the greater emphasis that must be placed on the relationships that can be established among them and the company.

\section{Stakeholder Engagement and Circular Business Models}

The establishment of circular business models underlines the importance of relationships with stakeholders, whose expectations are highly relevant for the formulation of a successful strategy (Hienerth et al., 2011; Horisch et al., 2014); in fact, these conditions are essential for the company's growth in the medium-to-long term (Salvioni et al., 2019).

Thus, "stakeholder engagement" (Freeman, 1994; Mitchell et al., 1997; Greenwood, 2007; Barone et al., 2013) can contribute to the implementation of circular business models. Such engagement can help companies identify stakeholder expectations and promote their fulfillment; in this regard, it is crucial to prevent potential negative effects due to the lack of an effective dialogue (Cumming, 2001). This approach requires the preliminary mapping and classification of stakeholders as well as the consequent selection of the most convenient ways of interaction (Gable, 2005).

The standard formulated by AccountAbility states that with reference to the engagement level (low, medium, or high) and the nature of the relationship (short, medium, or long term), engagement should be ensured through various communication approaches (enumerated below), which differ in terms of effectiveness and pervasiveness.

- Remain passive: No active communication is required, and the engagement is mainly based on letters, the media, and websites.

- Monitor: One-way communication (from the stakeholder to the organization) takes place through the media and internet tracking, and secondhand reports from other stakeholders, possibly via targeted interviews, are included in this category.

- Advocate: One-way communication (from the organization to the stakeholder) occurs via pressure on regulatory bodies, lobbying efforts, and other advocacy efforts through the social media.

- Inform: One-way communication (from the organization to the stakeholder) takes place through bulletins and letters, brochures, reports and websites, speeches, conferences, and public presentations. 
- Transact: Limited two-way engagement takes place through public-private partnerships, private finance initiatives, grant provisions, and cause-related marketing.

- Consult: Limited two-way engagement takes place, wherein the organization asks questions and the stakeholders answer them. This approach is based on surveys, focus groups, meetings with selected stakeholders, public meetings, and workshops.

- Negotiate: Limited two-way engagement occurs for discussions on a specific issue or a range of issues, the goal being to reach a consensus. This engagement mainly involves collective bargaining with workers through their trade unions.

- Involve: Two-way or multi-way engagement occurs, involving learning on all sides, but the stakeholders and organization act independently through multi-stakeholder forums, advisory panels, consensus-building processes, focus groups, and online engagement tools.

- Collaborate: Two-way or multi-way engagement takes place leading to joint learning and decision-making through joint projects, joint ventures, partnerships, multi-stakeholder initiatives, and online collaborative platforms; and

- Empower: Stakeholders play a relevant role in shaping organizational agendas; thus, their engagement is a key aspect in the firm's governance, strategy, and operations (AccountAbility, 2015).

The involvement of relevant stakeholders within circular models should be based on an integrated strategic approach in order to engage different stakeholders in achieving the company's strategic objectives (in particular, those established at the business level). In fact, "the organization shall integrate stakeholder engagement into all relevant policies and/or processes for strategy development" (AccountAbility, 2015).

Hence, a high level of engagement is recommended as a strategic approach for the effective establishment and implementation of circular business models. Indeed, the appraisal and analysis of the key stakeholders' expectations play a vital role in successful strategy formulation and implementation aimed at creating value in the medium-to-long term (Frooman, 1999; Hendry, 2005). In particular, the success of the selected business model is closely linked to the company's ability to establishing a long-term relationship with its stakeholders and fulfilling their expectations effectively in order to obtain their consent and trust (Svendsen, 1998; Post et al., 2002; Yaziji, 2004; Barney et al, 2007; Salvioni, 2018).

Stakeholder engagement is also emphasized in some international frameworks (Ellen McArthur Foundation, 2013; Accenture, 2014), clearly pointing to how companies should rethink their business models when implementing the principles of the circular economy. Such emphasis points to strategic resource usage and safeguarding the environment, which is increasingly adversely affected by soil degradation, water acidification, air pollution, waste generation, and carbon emissions. In fact, three of the nine so-called "key planetary boundaries", namely 
climate change, rate of biodiversity loss, and human interference with the nitrogen cycle, are believed to be the most adversely affected (Steffen et al., 2015).

The ability to create value is primarily associated with the following aspects: (a) reorientation of consumption to more responsible/environmentally aware behavior, (b) preferential use of sustainable and renewable resources, (c) adoption of measures lengthening product/service life cycles, (d) introduction of regulations (fiscal and non-fiscal) encouraging the conservation of the natural environment, (e) formulation of specific laws aimed at promoting the circularity of products/services (e.g., disposal of batteries, packaging, and textiles), (f) promotion of eco-innovation processes, (g) development of specific technical capabilities (green skills) and specialized profiles in the circular economy arena (e.g., circular economy manager) in order to adapt the organizational structure to the new strategic needs, (h) waste reduction and reconversion to secondary resources, (i) orientation of the firm toward corporate social responsibility principles, sustainable development, and climate neutrality, and (j) diffusion of an organizational culture based on ecosystem and biodiversity protection.

Within circular business models, the optimization of the company's performance requires the contributions of different stakeholders according to their specific roles and capabilities. Companies should ensure the engagement of relevant stakeholders before selecting the strategic objectives and implementing strategies. Indeed, the engagement of key stakeholders is a necessary condition for the implementation of decisions related to the circular economy, whose principles are generally based on stakeholders' responsible and ethical behaviors.

Thus, the need for engaging stakeholders - both internal and external - increases with time; in particular, attention must be focused on specific groups, as explained below.

- Consumers: their engagement is essential, both for understanding their expectations and for orientating them toward the virtuous practices of responsible and informed consumption. Effective engagement practices should ensure the diffusion and sharing of information required for identifying the available opportunities for the long-term use of materials (maintenance, reuse, refurbish, recycle, etc.) and sharing the use with other user groups. In particular, the reuse of products implies changing the role of the consumer to that of a potential supplier. Moreover, consumer engagement can serve as a source of learning and innovation as long as they play the role of co-producer in line with the proactive engagement approach (Kozlowski, 2018; Tolkamp et al., 2018).

- Suppliers: suppliers provide raw materials, which can be categorized as either biological or technical nutrients in reference to the two main components of the ecosystem (the biosphere and the technosphere, respectively). Supplier engagement should promote the sharing and alignment of values between suppliers and customers in order to ensure that procurement occurs according to the principles of circularity and sustainability (i.e., preferring renewable and socio-environmentally low-impact resources). Thus, the engagement of suppliers should be based on sharing the company's circular economy goals as well as their orientation toward renewable material choices.

- Government: government should encourage engagement to facilitate the understanding of the company's needs and the difficulties in implementing the transition toward the circular economy. In this context, Governments can 
introduce specific measures (subsidies, incentives, tax breaks, and funding startup ideas) to support innovative solutions for environmental protection.

- Industry partners: the engagement of industry partners may produce specific positive effects within the circular economy in terms of scale economies, profitable cost and risk sharing, potential logistic advantages, and better competitive positioning. The engagement and dialogue of these stakeholders should be carried out by analyzing and sharing the company's strategic objectives, involving industry representatives, and ensuring compliance with the principles of fair competition and transparency.

- Universities and research centers: the academic world pursues research, which is a potential innovation condition for firms that decide to renew their business models. It is important to establish relationships via dialogue and long-term interactions aimed at sharing know-how and selecting effective ways to introduce innovative circular products/services.

- Employees: employees must be engaged to ensure the development of new skills as well as reshape the values and ethical principles of the company's cultural system. Engagement of employees may promote the establishment of innovative processes aimed at reducing negative impacts on the ecosystem. Moreover, such engagement supports the organization's implementation of the circular economy's objectives selected by the governance bodies to promote reuse and recycling by consumers.

- Investors: investors' financial support for a company's strategic decisions is based on the communication and sharing of its strategic objectives. In particular, the engagement process involving investors is relevant for cases with highly fragmented ownership (in terms of the relationship between shareholders and the management).

Thus, the adoption of a stakeholder engagement strategy is essential for undertaking circular practices. It requires the (a) active engagement of consumers in specific production processes, as their role may contribute to innovation (coinnovation) and improved environmental safeguarding, (b) formulation of strategies implying the transformation of consumers into suppliers, (c) introduction of measures encouraging product reuse at the end of the first consumption stage (cash rebates, discounts for future purchases, pre-paid shipping for returned products, etc.), (d) engagement of responsible suppliers while supporting the experiences and capabilities they have developed in the circular economy field using specific measures (joint research, economic incentives, cost sharing, etc.), (e) continuous dialogue with the standard setters and Government in order to introduce measures supporting investments in the circular economy, (f) establishment of industry partnerships aiming to promote innovative processes to safeguard the ecosystem (cross-fertilization and joint venture agreements), (g) communication with investors regarding the actions taken to reduce environmental impacts, (h) establishment of sharing, partnering, and networking relationships between stakeholders and companies (Rossignoli, et al. 2018), (i) development of new professional profiles to adapt current skills and capabilities in the circular economy process, and (j) information sharing within the organization regarding the actions taken to limit resource consumption.

Thus, stakeholder engagement strategies may differ depending on the key stakeholders that can be engaged with respect to the selected business model. 
Generally, it is possible to distinguish between stakeholder engagement strategies based on stakeholder types, namely internal (employees and shareholders) and external (customers and suppliers). The former are relevant in all cases, as they relate to acquisitions of specific skills and economic resources required by any business model based on waste reduction. Conversely, the latter tend to refer mainly to business models focused either on circular supply chains or on the lengthening of product life cycle, with consequent emphasis on suppliers and customers.

It is evident that rethinking a business model according to stakeholder engagement principles requires a shift from the traditional economic "customer-oriented" perspective toward a "multiple stakeholder" approach characterized by high integration and circularity (Payne et al., 2002; Matos et al., 2013). In this regard, increasing attention is being paid at the international level to the circular economy together with a corresponding push toward the engagement and dialogue of relevant stakeholders who play a growing strategic role. Indeed, evidence of this is available from different industries, which share a common approach based on the understanding that the engagement and dialogue of relevant stakeholders, as well as the sharing of strategic objectives, is a necessary condition for a company's longterm success.

\section{3. "Firm-Stakeholder" Engagement Relationships}

The development of successful business models is supported by the establishment of engagement relationships between the firm and its relevant stakeholders. Twoway communication is essential for a proactive approach. In this regard, Andriof and Waddock stated that, "[...] stakeholder engagement is premised on the belief that progressive companies have moved from reactive compliance-oriented management of social issues through proactive boundary spanning functions that cope more effectively with external matters and into interactive management strategies with a range of stakeholders important in a company's network" (Andriof et al., 2002, p. 42).

Many best practices can be identified within the circular economy field; they are characterized by the effort in engaging stakeholders according to widely renewed business models. In particular, the strategic use of both technical and biological resources by reducing wastes and negative environmental impacts is crucial for all industries, and even quite specific for those belonging to certain sectors (Lacy et al., 2015; Mendoza et al., 2017).

For example, consider the one of the leaders of the energy industry, the Italian listed company Eni, whose business model is based on a combination of different approaches.

\footnotetext{
$\square$ «The mainstays of Eni's circularity strategy are:

- sustainable raw material: than is processing increasingly less virgin inputs and moving towards the use of materials of biological origin or derived from production process waste;

- reuse, recycling, and recovery: by processes for raw material recovery from waste products, reuse of water and land, as well
} 
as recovery of waste; and extension of useful life: giving new life to assets with a view of sustainability [...].

A transformative attitude and the circularity platform are, for Eni, the basis for reinforcing a change in our long-term relationships with local stakeholders, on the attention to the specificity of local communities and on listening to, and the inclusion of stakeholders in advancing the new development model». (Eni, 2019a)

" [...] The relationships with its stakeholders, listening and sharing decisions with people in the Countries where it operates are fundamental elements: knowledge of their point of view and their expectations is the foundation of its commitment to building transparent and lasting relationship based on mutual trust.»(Eni, 2019b)

With reference to the engagement of its employees, Eni states the following:

$\square$ «In 2019, Eni completed the fourth edition of the climate analysis - Eni secondo te. This analysis represented a fully inclusive project to allow the broadest possible participation, with a survey in 11 languages. [...] The engagement level rose from $81 \%$ to $84 \%$. This result indicates how much the people feel emotionally and rationally involved in the organization and motivated to strive for this success. [...]» (Eni, 2019a).

"In 2019, engagement and training activities continued for Eni employees on issues related to climate change and the environment in order to increase internal awareness of the importance of these issues. In addition to the technical training courses for the functions directly involved, online training courses on climate change and energy transition have been created and are available to all employees. [...] Additionally, the CEO constantly brings the Company's results in terms of reducing the carbon footprint of its activities and the actions needed to implement its carbon neutrality strategy to the attention of the employees.» (Eni, 2019b)

«Every person contributes to creating value in support of Eni's goals and major transformations: in order to increase the team spirit and optimise the contribution of everyone it is essential to get everyone to share and engage in the business model, results, goals and strategies.» (Eni, 2019c)

With regard to its suppliers, the company notes the following:

$\square$ «[...] is also carrying out numerous engagement initiative with suppliers, for example: local meetings for local companies, organized in collaboration with trade associations and/or local authorities, during which Eni's sustainability values and principles are illustrated [...]. Eni, moreover, is finalizing and subsequently diffusing a code of conduct for suppliers, which confirms the 
importance of the respect for the cardinal principles of sustainability in the supply chain.» (Eni, 2019a).

With reference to stakeholders such as the international institutions, customers, universities and research centers, and trade associations, the following actions are being implemented by Eni:

$\square$ «eetings with Italian political representatives and
institutions, both central and local, on energy, climate and
environmental issues, circular economy and sustainable
development»; «meeting and workshops with Presidents,
Secretaries General and Energy Managers of national and local
Consumer's Associations on issues such as sustainability, circular
economy, reclamation and environmental remediation.
Sponsorship of Consumer's Associations initiatives on
sustainability and circular economy. Territorial meeting with the
regional Consumer's Associations of the Italian National Council
of Consumers and Users. Survey of national and regional
Consumer's Associations representatives on circular economy,
sustainability and energytransition»; «establishment with the CNR
of 4 research centres in Southern Italy for sustainable
environmental and economic development in Italy and worldwide.
Collaboration with the Polytechnic of Milan in the organization of
the Master's in Energy Innovation and for the development of
Impact Assessment Models»; «conferences, debates, seminars and
training initiatives on sustainability issues (energy, circular
economy, remediation, corporate social responsibility);
implementation of guidelines and sharing of best practices.» (Eni,
2019a)

With reference to the food industry, it is important to underline the experience of the American grocery chain Kroger, whose circular economy approach is based on a business model typically known as "resource recovery". In this regard, Kroger states:

$\square$ «we know $40 \%$ of food produced in the U.S. is thrown out, yet one in eight people in our country are food insecure-perhaps even someone we know. Redirecting just one-third of the food wasted in the U.S. every year would more than feed those struggling with hunger. Reducing the amount of wasted food in landfills in considered one of the top solutions to reserve the effects of climate change. We can help.»

"In 2018, we diverted 128,000 tons of food waste to animal feed operations. Currently, 2,039 stores have program in place to divert food waste to animal feed, composting and anaerobic digestion operations.»

"Food that cannot be sold or donated should be recycled through animal feed, anaerobic digestion or composting. We have food waste recycling programs in 2,039 stores - up from 1,978 at the 
end of 2017 - and we're working to bring these programs to every store.» (Kroger, 2019)

Kroger emphasizes the relevance of customer engagement, as follows:

$\square$ «According to research, approximately $40 \%$ of food waste happens at the consumer level in our customers' homes. In 2018, Kroger launched a series of communications aimed at giving our customers the tools and information needed to reduce waste at home. A highlight is our Wilted to Wonderful series, which features stories on www.krogerstories.com, including blogs, videos, and recipe ideas about using expiring food, such as left-overs [...]. We offer our valued customers many ways to engage with Kroger and share their ideas, feedback, opinions, and concerns on an ongoing basis. These include in-store service counters, surveys, focus groups, web sites, and social media.» (Kroger, 2019)

Kroger is mindful of its other stakeholders as well; with reference to labor unions, Kroger states that:

$\square$ «We communicate on a regular basis with our local and international unions, which represent many of our associates, through scheduled meetings, telephone calls, and ongoing collective bargaining agreement negotiations throughout the year.» (Kroger, 2019)

With reference to suppliers, Kroger specifies that:

$\square$ «Kroger's engagement with our suppliers is a critical element of our commitment to responsible sourcing and supplier accountability. We focus our engagement during the onboarding process and continue it through ongoing meetings, site visits, surveys, audits, and scorecards.»

Similarly, with reference to policy makers and government agencies, Kroger declares that:

$\square$ «We engage government officials and policymakers across the country at the national, state, and local levels to increase awareness of Kroger's operations and commitment as a responsible grocery retailer. Key channels include meetings and briefings, advocacy and participation in select government and civic associations.»

Kroger also engages its shareholders and the community.

$\square$ «Kroger's leaders, [...], engage with shareholders throughout the year to discuss important topics related to the business"; "the 
Kroger family of companies is committed to community engagement, positive social impact, and charitable giving at a national and local levels. [...] Our Corporate Affairs team is responsible for community engagement in partnership with the company's senior officer and leaders.»

The Danish firm Novozymes is an excellent example in the biotechnologies sector; its circular business model refers to the "circular supplies" typology. Novozymes conducts all research, development, and production of industrial enzymes, microorganisms, and biopharmaceutical ingredients following the principles of sustainability to manufacture low-impact products. With reference to its employee and community engagement activities, Novozymes states:

$\square$ «Novozymes will also focus on employee engagement and
motivation to ensure the employee spirit remains high [...]. We
believe that businesses have a responsibility to engage with the
communities in which they operate and invest strategically in
programs that create value for society. We focus our community
engagement and social investment activities on education, which
we believe is crucial for global sustainable development. [...]
Novozymes believes that customer opinions serve as powerful
indicator in determining the success and performance of its
solutions in the market. [...] Each year we conduct a satisfaction
survey of our customers across all divisions. This is to monitor
customer perceptions of our solutions and services and learn
where we can improve.» (Novozymes, 2019)

With regard to the technology industry, the American firm Hewlett Packard, a hardware and software technologies company, is characterized by a circular business model related to the "product as a service" typology. In this regard, the firm explains the following:

$\square$ «Traditionally, many customer-owned IT systems are significantly underutilized, with spare data storage and processing capacity. This is financially and environmentally inefficient. Our as-a-service model means our customers use only the capacity they need. Matching capacity to demand reduces the environmental impact of their IT - a step forward achieving the promise of the digital frontier within the limits of the planet. Our as-a-service model is also a step forward circular IT, taking care of equipment end-use for customers.» (Hewlett Packard, 2019)

In order to implement the above-mentioned business model, the firm engages specific stakeholder groups, namely team members, customers, and investors.

$\square$ «We regularly collaborate with our stakeholders through varying approaches such as partnerships, industry forums, 
supplier capability building, direct customer engagements, mentoring surveys and assessments" [...] "Team member engagement is key to HPE's cultural transformation and we're proud to share that our team members are more engaged than even before"; "In addition to face-to face engagements with customers, HPE offers a direct channel for customers and stakeholder inquiries through our Sustainability Contact center"; "HPE actively engages with investors regarding our approach to ESG issues management and performance.» (Hewlett Packard, 2019)

Another good example of a company in the technology industry is that of Apple, which adopts a "product life extension" business model.

$\square \ll$ Our strategy is to create circular supply chains and reduce our impact on the planet's resources by: [...] making long-lasting products by designing highly durable hardware, creating a broad network of repair providers, and ensuring software compatibility with older models.» (Apple, 2019)

With reference to stakeholder engagement, Apple states the following:

$\square$ «We seek to engage customers in our environmental mission, giving them the opportunities to join in our efforts. In the past three years, we have launched two customer-facing campaigns: Apps for Earth, and communications around the benefits of returning devices to Apple for trade-in or recycling... Over the past several years, we have invited key stakeholders to participate in roundtables in Europe, United States, and China to obtain feedback on Apple's key environmental programs.» (Apple, 2019)

Finally, the "sharing platforms" business model may be identified with reference to the American firm Uber, which specifies:

$\square$ «our internationally growth strategy has included the restructuring of our business and assets in certain jurisdictions by partnering with and investing in local ridesharing and meal delivery companies to participate in those markets rather than operate in those markets independently.» (Uber, 2019)

With regard to stakeholder engagement, Uber declares:

$\square$ «the Company derives its New Mobility revenue from operating leases as defined within ASC 842, "Leases" ("ASC 842"). New Mobility refers to offerings and products that provide users with access to rides through a variety of modes, including dockless ebikes and e-scooters ("New Mobility"). New Mobility also includes Transit, UberWorks and the Company's Platform Incubator group, which is responsible for innovating new services and use cases on 
the Company's platform to drive long-term growth and crossplatform customer engagement.»

[...] «We believe that all of these synergies serve the customer experience, enabling us to attract new platform users and to deepen engagement with existing platform users. Both of these dynamics grow our network scale and liquidity, which further increases the value of our platform to platform users.»

[...] «Maintaining and enhancing our brand and reputation is critical to our ability to attract new employees and platform users, to preserve and deepen the engagement of our existing employees and platform users, and to mitigate legislative or regulatory scrutiny, litigation, government investigations, and adverse platform user sentiment.» (Uber, 2019).

\section{Stakeholder Engagement and the Circular Economy Culture}

The effective rethinking of business models according to circularity and stakeholder engagement principles requires, first and foremost, a deep cultural change. Indeed, the corporate culture refers to the values, principles, behaviors, expectations, and beliefs related to the vision of the firm's corporate governance body (Clemente et al., 1999; Brondoni, 2010; Salvioni, 2010). These values characterize the company's internal dimension, thus playing a role in the behaviors of all of its members.

The implementation of behaviors based on the sustainable use of technical and biological resources requires the (a) diffusion and sharing among all stakeholders of a culture focused on responsible consumption, (b) willingness to contribute to safeguarding the ecosystem by reducing the impacts of the company's activities, (c) promotion of product/service reuse, recycle, and refurbishment behaviors instead of waste generation, (d) orientation toward long-term value creation according to sustainability principles, and (e) establishment of inclusive stakeholder engagement approaches. In this regard, it is possible to state that the establishment of circular business models first requires the development of the so-called "circular economy culture", which refers to a specific sub-set of environmental and biodiversity protection values and principles within the wider corporate cultural system. The rearrangement of production processes as well as of the supply chain and distribution channels without a deep rethinking of the traditional cultural linear economy model is likely to be either useless, or even the source of loss due to inefficiencies, potential reputational damage, poor investment choices, etc. Thus, it is necessary to understand that the costs entailed in reuse are lower than those borne in case of discarding waste (Hopkinson et al., 2018).

The circular economy culture should be based on a "cautious" approach with reference to the use of the limited resources available; this new perspective is clearly expressed in the principle introduced by Stahel (2010): "do not repair what is not broken, do not remanufacture something that can be repaired, do not recycle a product that can be remanufactured. Replace or treat only the smallest possible part in order to maintain the existing economic value of the technical system". 
Thus, effective transition toward the circular economy model requires rethinking of the basic values identified by a firm's leaders and shared within the organization. Indeed, establishing a circular business model entails a wide rearrangement of the value creation approach, and companies can ensure this by developing a culture based on the circular economy and sustainable development principles. In this regard, it is necessary to ensure alignment among the corporate culture, business models, and the firm's strategy (Delery et al., 1996). Thus, it is important to promote an inclusive approach as an essential condition for dialogue with the most relevant stakeholders (Rebs, 2018). Indeed, the rethinking of business models according to wide circularity conditions can be supported by the ability to conduct dialogues with stakeholders, in order to identify their expectations before selecting the direction for re-orienting the company's activities.

The change in approach should also be based on a widespread cultural rethinking related to corporate social responsibility, which considers not only the economic effects, but also the social and environmental ones. This perspective underlines the relevance of key stakeholder engagement according to an integrated approach based on the appraisal of the different interests involved, the goal being to guide all stakeholders toward behaviors aligned with the new conditions of supply, consumption, labor, product use and development of significant competitive abilities.

\section{Emerging Issues}

Stakeholder engagement is assuming growing relevance as an approach supporting the success of circular business models. In fact, the company's ability to listen to and engage relevant stakeholders and the possibility of creating value in the long term are directly related to establishing positive relationships based on trust, consent, and sharing of principles and behaviors.

Developing a dialogue with key stakeholders is strategically relevant to achieve the objectives selected by a firm's corporate governance body. This belief is based on the understanding of the different roles and contributions of stakeholders-and consequently, the different kinds of engagement required-with regard to the business model adopted. However, the engagement of key stakeholders according to a proactive, inclusive, and integrated approach is a strategic condition that supports the effective shift from a linear economy model toward a circular one.

To ensure the effectiveness of a circular business model, a change in cultural values at the topmost level of the firm and its sharing with the organization are essential. These values should be aligned along the principles of responsible consumption, sustainable production and supply chains, and safeguarding ecosystems and health.

The capacity to integrate the selected strategic objectives with stakeholder engagement is a key challenge for companies that decide to implement circular business models. Companies must develop the ability to identify, listen to, and engage with stakeholders that are actually relevant for the implementation of their strategy, considering the new conditions implied by the circular economy model. In this regard, this study underlines the strategic relevance of engaging specific stakeholders in order to establish successful business models, while simultaneously underscoring the need to better investigate the firm's behaviors through a wider empirical analysis. 
Our study contributed to the existing literature by exploring the manner in which firms conduct stakeholder engagement with regard to optimizing the transition of business models toward a circular system. Moreover, this topic can be analyzed with reference to more specific research areas, such as the different aspects related to the diffusion of a sustainability culture among external stakeholders, supporting the functioning of circular business models, integration of circular models and internal control systems for the effective engagement of firms' members, and typologies of the relationships established between companies and the Government with regard to creating and maintaining the circular economy.

\section{Bibliography}

Aboulamer, A. (2017). Adopting a Circular Business Model Improves Market Equity Value. Thunderbird International Business Review, 60(5), 765-769.

http://dx.doi.org/10.1002/tie.21922

Accenture (2014). Circular Advantage. Innovative Business Models and Technologies to Create Value in a World without Limits to Growth.

AccountAbility (2015). AA1000. Stakeholder Engagement Standard.

Akanbi, L. Oyedele, L.O., Omoteso, K. \& Owolabi, H.A. (2019). Disassembly and Deconstruction Analytics System (D-DAS) for Construction in a Circular Economy, Journal of Cleaner Production, June, (223), 386-396.

http://dx.doi.org/10.1016/j.jclepro.2019.03.172

Almici, A. (2012). Corporate Governance, Sustainable Development and Value Creation. Some Evidences from Italian Listed Companies. Chinese Business Review, 11(3), 322-333.

Andriof, J., \& Waddock, S. (2002). Unfolding Stakeholder Engagement: Theory, Responsibility and Engagement, in Andriof, J., Waddock, S., Husted, B., \& Sutherland Rahman, S. (eds), Unfolding Stakeholder Thinking. Sheffield: Greenleag Publishing.

http://dx.doi.org/10.4324/97811351281881-2

Apple (2019). Environmental Responsibility Report.

Barney, J., \& Clark, D. (2007). Resource-Based Theory: Creating and Sustaining Competitive Advantage. Oxford: Oxford University Press.

Barone, E., Ranamagar, N., \& Solomon, J. F. (2013). A Habermasian Model of Stakeholder (Non)Engagement and Corporate (Ir)Responsibility Reporting. Accounting Forum, 37(3), 163-181. http://dx.doi.org/10.106/j.accfor.2012.12.001

Beattie, V., \& Smith, S. J. (2013). Value Creation and Business Models: Refocusing the Intellectual Capital Debate. British Accounting Review, 45(4), 243-254.

http://dx.doi.org/10.1016/j.bar.2013.06.001

Bocken, N. M. P., Short, S. W., Rana, P., \& Evans, S. (2014). A Literature and Practice Review to Develop Sustainable Business Model Archetypes. Journal of Cleaner Production, 65(4), 42-56.

http://dx.doi.org/10.1016/i.jclepro.2013.11.039

Bonciu, F. (2014). The European Economy: From a Linear to a Circular Economy. Romanian Journal of European Affairs, 14(4), 78-91.

Brondoni S. M. (2010). Intangibles, Global Networks \& Corporate Social Responsibility. Symphonya. Emerging Issues in Management (symphonya.unimib.it), (2), 6-24.

http://dx.doi.org/10.4468/2010.2.02brondoni

Brondoni, S. M. (2014). Global Capitalism and Sustainable Growth. From Global Products to Network Globalisation, Symphonya. Emerging Issues in Management (symphonya.unimib.it), (1), 10-31.

http://dx.doi.org/10.4468/2014.1.02brondoni 
Brondoni, S. M. (2019). Shareowners, Stakeholders \& the Global Oversize Economy. The Coca-Cola Company Case. Symphonya. Emerging Issues in Management (symphonya.unicusano.it), (1), 16-27. http://dx.doi.org/10.4468/2019.1.02brondoni

Chesbrough, H. (2010). Business Model Innovation: Opportunities and Barriers. Long Range Planning, 43 (2-3), 354-363.

http://dx.doi.org/10.1016/j.lrp.2009.07.010

Clemente, M. N., \& Greenspan, D. S. (1999). Culture Clashes, Executive Excellence, 16(10), 12.

Cumming, J. F. (2001). Engaging Stakeholders in Corporate Accountability Programmes: A CrossSectional Analysis of UK and Transnational Experience. Business Ethics: A European Review, 10 (1), 45-52.

http://dx.doi.org/10.1111/1467-8608.00211

Delery, J. E., \& Doty, D. H. (1996). Modes of Theorizing in Strategic Human Resource Management: Test of Universalistic, Contingency, and Configurational Performance Predictions. Academy of Management Journal, (39), 802-35.

http://dx.doi.org/10.2307/256713

Dentchev, N., Rauter, R., Johannsdottir, L., Snihur, Y., Rosano, M., Baumgartner, R., Nyberg, T., Tang, X., van Hoof, B., \& Jonker, J. (2018). Embracing the Variety of Sustainable Business Models: a Prolific Field of Research and a Future Research Agenda. Journal of Cleaner Production, 194, 695-703.

http://dx.doi.org/10.1016/j.jclepro.2018.05.156

Donaldson, T., \& Preston, L. E. (1995). The Stakeholder Theory of the Corporation: Concepts, Evidence, and Implications. Academy of Management Review, 20 (1), 65-91.

http://dx.doi.org/10.2307/258887

Ellen MacArthur Foundation (2013). Towards the Circular Economy, London.

Ellen Mac Arthur Foundation (2014). Rethink the future, London.

Ellen MacArthur Foundation (2015). Growth within: A Circular Economy Vision for a Competitive Europe, London.

Eni (2019a). Carbon Neutrality in the Long Term, Eni for 2019.

Eni (2019b). A Just Transition, Eni for 2019.

Eni (2019c). Sustainability Performance, Eni for 2019.

European Commission (2012). Manifesto for a Resource-Efficient Europe, European Commission Memo 12/989.

European Commission (2014). Towards a Circular Economy: A Zero Waste Programme for Europe, Communication to the European Parliament, the Council, the European Economic and Social Committee of the Regions. Document COM (2014) 398 final, Brussels, 2.07.2014.

European Commission (2015). Closing the Loop. An EU Action Plan for the Circular Economy.

European Commission (2020). Circular Economy Action Plan.

Freeman, E. R. (1994). The Politics of Stakeholder Theory: Some Future Directions. Business Ethics Quarterly, 4(4), 409-421.

http://dx.doi.org/10.2307/3857340

Frooman, J. (1999). Stakeholder Influence Strategies. Academy Management Review, 24 (2), 191-205. http://dx.doi.org/10.2307/259074

Gable, C., \& Shireman, B. (2005). Stakeholder Engagement: A Three Phase Methodology. Environmental Quality Management, 14, 9-24.

http://dx.doi.org/10.1002/tqem.20044

Geisendorf, S., \& Pietrulla, F. (2017). The Circular Economy and Circular Economic Concepts: A Literature Analysis and Redefinition. Thunderbird International Business Review, 60 (5), 771-782. http://dx.doi.org/10.1002/tie.21924

Geissdoerfer, M., Savaget, P., Bocken, N. M. P., \& Hultink, E. J. (2017). The Circular Economy - A New Sustainability Paradigm? Journal of Cleaner Production, 143, 757-768. 
http://dx.doi.org/10.1016/j.jclepro.2016.12.048

Ghisellini, P., Cialiani, C., \& Ulgiati, S. (2016). A review on Circular Economy: The Expected Transition to a Balanced Interplay of Environmental and Economic Systems. Journal of Cleaner Production, 114, 11-32.

http://dx.doi.org/10.1016/j.jclepro.2015.09.007

Greenwood, M. (2007). Stakeholder Engagement: Beyond the Myth of Corporate Responsibility. Journal of Business Ethics, 74, 315-327.

http://dx.doi.org/10.1007/s10551-007-9509-y

Gregson, N., Crang, M., Fuller, S., \& Holmer, H. (2015). Interrogating the Circular Economy: The Moral Economy of Resource Recovery in the EU. Economy and Society, 44(2), 218-243.

http://dx.doi.org/10.1080/03085147.2015.1013353

Haas, W., Krausmann, F., Wiedenhofer, D., \& Heinz, M. (2015). How Circular Is the Global Economy: An assessment of Material Flows, Waste Production and Recycling in the European Union and the World in 2005. Journal of Industrial Ecology, 19(5), 765-777.

http://dx.doi.org/10.1111/jiec.12244

Hendry, J. R. (2005). Stakeholder Influence Strategies: An Empirical Exploration. Journal of Business Ethics, 61(1), 79-99.

http://dx.doi.org/10.1007/s10551-005-8502-6

Hewlett Packard (2019). Living Progress Report.

Hienerth, C., Keinz, P., \& Lettl, C. (2011). Exploring the Nature and Implementation Process of Usercentric Business Models. Long Range Planning, (44), 344-374.

http://dx.doi.org/10.1016/j.lrp.2011.09.009

Hollander, M. C., Bakker, C. A., \& Hultink, E. J. (2017). Product Design in a Circular Economy; Development of a Typology of Key Concepts and Terms. Journal of Industrial Ecology, 21(3), 517-525. http://dx.doi.org/10.1111/jiec.12610

Hopkinson, P., Zils, M., Hawkins, P., \& Roper, S. (2018). Managing a Complex Global Circular Economy Business Model: Opportunities and Challenges. California Management Review, 60(3), 71-94.

http://dx.doi.org/10.1177/0008125618764692

Hörisch, J., Freeman, R., \& Schaltegger, S. (2014). Applying Stakeholder Theory in Sustainability Management: Links, Similarities, Dissimilarities, and Conceptual Framework. Organisation \& Environment, 27(4), 328-346.

http://dx.doi.org/10.1177/1086026614535786

Jackson, T. (2009). Prosperity without Growth: Economics for a Finite Planet. London: Earthscan.

Kirchherr, J., Reike, D., \& Hekkert, M. (2017). Conceptualizing the Circular Economy: An Analysis of 114 Definitions. Resources, Conservation and Recycling, 127(12), 221-232.

http://dx.doi.org/10.1016/j.resconrec.2017.09.005

Kolk, A. (2016). The Social Responsibility of International Business: From Ethics and the Environment to CSR and Sustainable Development. Journal of World Business, 51(1), 23-34.

http://dx.doi.org/10.1016/j.jwb.2015.08.010

Kozlowski, A., Searcy, C., \& Bardecki, M. (2018). The Redesign Canvas: Fashion Design ad a tool for Sustainability. Journal of Cleaner Production, 183(14), 194-207.

http://dx.doi.org/10.106/j.clepro.2018.02.010

Kroger (2019), Environmental, Social \& Governance (ESG) Report.

Lacy, P., \& Rutqvist, J. (2015). Waste to Wealth: The Circular Economy Advantage. Basingstoke: Palgrave Macmillian.

Lambin, J. J. (2009). Capitalism and Sustainable Development, Symphonya. Emerging Issues in Management (symphonya.unimib.it), (2), 3-9.

http://dx.doi.org/10.4468/2009.2.02lambin 
Lambin, J. J. (2014). Rethinking the Market Economy. Symphonya. Emerging Issues in Management (symphonya.unimib.it), (2), 4-15.

http://dx.doi.org/10.4468/2014.2.02lambin

Linder, M., \& Williander, M. (2015). Circular Business Model Innovation: Inherent Uncertainties. Business Strategy and the Environment, 26(2), 182-196.

http://dx.doi.org/10.1002/bse.1906

Ma, S., Wen, Z. Z., Chen, J., \& Wen, Z. Z. (2014). Mode of Circular Economy in China's Iron and Steel Industry: A Case Study in Wu'an city. Journal of Cleaner Production, 64, 505-512. http://dx.doi.org/10.1016/j.jclepro.2013.10.008

Matos, S., \& Silvestre, B. S. (2013). Managing Stakeholder Relations when Developing Sustainable Business Models: The Case of Brazilian Energy Sector. Journal of Cleaner Production, 45(7), 61-73. http://dx.doi.org/10.1016/j.jclepro.2012.04.023

McDonough, W., \& Braungart, M. (2002). Cradle to Cradle: Remaking the Way We Make Things. New York: North Point Press.

Mendoza, J. M. F., Sharmina, M., Gallego-Schmid, A., Heyes, G., \& Azapagic, A. (2017). Integrating Backcasting and Eco-design for the Circular Economy: The BECE Framework. Journal of Industrial Ecology, 21(3), 526-544

http://dx.doi.org/10.1111/jiec.12590

Mitchell, R. K., Agle, B. R., \& Wood, D. J. (1997). Toward a Theory of Stakeholder Identification and Salience: Defining The Principle of Who and What Really Counts. Academy Management Review, 22(4), 853-886.

http://dx.doi.org/10.2307/259247

Novozymes (2019). The Novozymes Report 2019.

OECD (2019). Business Models for a Circular Economy Opportunities and Challenges from a Policy Perspectives.

Osterwalder, A., Pigneur, Y., Smith, A., \& Movement, T. (2010). Business Model Generation: A Handbook for Visionaries Game Changers and Challengers. New Jersey: John Wiley \& Sons.

Payne, S. L., \& Calton, J. M. (2002). Towards a Managerial Practice of Stakeholder Engagement: Developing Multi-stakeholder Learning Dialogues. The Journal of Corporate Citizenship, 6(2) 37-52. http://dx.doi.org/10.9774/GLEAF.4700.2002.su.00006

Post, J. E., Preston, L. E., \& Sachs, S. (2002). Managing the Extended Enterprise: The New Stakeholder View. California Management Review, 45(1), 6-28.

http://dx.doi.org/10.2307/41166151

Ranta, V., Aarikka-Stenroos, L., \& Makinen, S. J. (2018), Creating Value in the Circular Economy: A Structured Multiple-case Analysis of Business Models. Journal of Cleaner Production, 201(11), 988-1000.

http://dx.doi.org/10.106/j.jclepro.2018.08.072

Rebs, T., Brandenbur, M., Seuring, S., \& Stholer, M. (2018). Stakeholder Influences and Risks in Sustainable Supply Chain Management: A Comparison of Qualitative and Quantitative Studies. Business Research, 2(2), 197-237.

http://dx.doi.org/10.1007/s40685-017-0056-9

Rossignoli, F., \& Lionzo, A. (2018). Network Impact on Business Models for Sustainability: Case Study in the Energy Sector. Journal of Cleaner Production, 182(13), 694-704.

http://dx.doi.org/10.1016/j.jclepro.2018.02.2015

Salvioni, D. M. (2010). Intangible Assets and Internal Controls in Global Companies. Symphonya. Emerging Issues in Management (symphonya.unimib.it), (2), 39-51.

http://dx.doi.org/10.4468/2010.2.4salvioni

Salvioni, D. M. (2018). Corporate Governance, Ownership and Global Markets, in Brondoni, S. M. (ed.), Competitive Business Management. A Global Perspective. New York \& Turin: Routledge \& Giappichelli. 
Salvioni, D. M., \& Astori, R. (2013). Sustainable Development and Global Responsibility in Corporate Governance, Symphonya. Emerging Issues in Management (symphonya.unimib.it), (1), 28-52.

http://dx.doi.org/10.4468/2013.1.03salvioni.astori

Salvioni, D. M., \& Gennari, F. (2017). CSR, Sustainable Value Creation and Shareholder Relations. Symphonya. Emerging Issues in Management (symphonya.unimib.it), (1), 36-49.

http://dx.doi.org/10.4468/2017.1.04salvioni.gennari

Salvioni, D. M., \& Gennari, F. (2019). Stakeholder Perspective of Corporate Governance and CSR Committees. Symphonya. Emerging Issues in Management (symphonya.unicusano.it), (1), 28-39.

http://dx.doi.org/10.4468/2019.1.03salvioni.gennari

Stahel, W. R. (2010). The Performance Economy. London: Palgrave Macmillian.

Steffen, W., Richardson, K., Rockström, J., Cornell, S.E., Fetzer, I., Bennet, E.M., Biggs, R., Carpenter, S. R., de Vries, W., de Wit, C. A., Folke, C., Gerten, D., Heinke, J., Mace, G., Persson, L. M., Ramanathan, V., Reyers, B., \& Sörlin, S. (2015). Planetary Boundaries: Guiding Human Development on a Changing Planet. Science, 347 (6223).

http://dx.doi.org/10.1126/science.1259855

Svendsen, A. (1998). The Stakeholder Strategy: Profiting from Collaborative Business Relationships. San Francisco: Berret-Koehler.

Teece, D. J. (2010). Business Models, Business Strategy and Innovation. Long Range Planning, 43(23), 172-194.

http://dx.doi.org/10.1016/j.1rp.2009.07003.

Tolkamp, J., Huijben, J. C. C. M., Mourik, R. M., Verbong, G. P. J., \& Bouwknegt, R. (2018). UserCentred Sustainable Business Model Design: The Case of Energy Efficiency Services in the Netherlands. Journal of Cleaner Production, 182(13), 755-764.

http://dx.doi.org/10.1016/j.jclepro.2018.02.032

Uber (2019). Annual report.

Wells, P. E. (2013). Business models for Sustainability. Cheltenham: Edward Elgar Publishing Limited.

Yaziji, M. (2004). Turning Gadflies into Allies. Harvard Business Review, 82(2), 110-115. 